\title{
Asymmetric Effects of Oil Prices on the Manufacturing
}

\author{
Sector in Turkey*
}

C. Emre Alper ${ }^{\dagger}$ and Orhan Torul ${ }^{\ddagger}$

\begin{abstract}
We investigate the relationship between oil prices and manufacturing sector of a small open economy, Turkey. We take into account exogeneity of oil prices, extreme oilreliance and import-dependence, as well as asymmetric responses of oil product prices to world crude oil price changes. We also control for the global liquidity and domestic finance conditions, along with real exchange rate dynamics in our VAR estimations. We report that while oil price increases do not significantly effect the manufacturing sector in aggregate terms, some sub-sectors are adversely affected.
\end{abstract}

Keywords: Petroleum Derivative Price, Global Liquidity, Small Open Economy

*An earlier version of this paper was presented at the 31st IAEE International Conference in Istanbul, June 2008, as well as at the 29th Annual Conference of MEEA in San Francisco, January, 2009. We wish to thank to IAEE and MEEA Conference participants, and Oya Pınar Ardıç, Burak Saltoğlu, Ünal Zenginobuz for helpful comments and discussions. Alper acknowledges financial support from TUBA-GEBIP (Turkish Academy of Sciences - Young Scientists Scholarship Program). The usual disclaimer applies.

${ }^{\dagger}$ Department of Economics. Bogazici University, Istanbul 34342, Turkey. Email: alper@boun.edu.tr

${ }^{\ddagger}$ Corresponding Author. Department of Economics, University of Maryland, College Park, MD 20742, USA. Email: torul@econ.umd.edu 


\section{Introduction}

Understanding the nature of the relationship between oil price and real output has been an issue of concern to both policymakers and researchers in the recent decades. While numerous studies have achieved remarkable progress in explaining the dynamics for the U.S. and other developed economies ${ }^{1}$, there are relatively few studies devoted to developed economies, and almost none to oil-importing small open economies such as Turkey.

Turkish economy distinguishes from the U.S. and other examined developed and/or oilproducing economies in several aspects: First, Turkey is a small open economy which can influence neither the world oil demand nor the supply ${ }^{2}$, hence when compared to the previously examined countries, oil price changes can be taken as exogenous to the Turkish economy.

Second, since compared to rest of the OECD countries Turkey depends heavily on oil imports for energy production and consumption ${ }^{3}$, oil price movements are expected to have more drastic effects on Turkish economy. The ratio of oil expenditure to GDP is higher ${ }^{4}$, and imports of oil and natural gas is an important contributor to the current account deficit. In figure 1, we display the historical pattern of current account balance of Turkey with and without oil and natural gas expenditures. By the beginning of the year 2008, the annualized current account deficit is slightly higher than 5\% of Turkey's GDP and oil imports account for almost $40 \%$ of this ratio alone, and together with natural gas imports this ratio adds up to $68 \%$.

\footnotetext{
${ }^{1}$ See Mork (1989), Lee et al (1995), Hamilton $(1996,2003)$ on asymmetric effects of oil prices on aggregate output, Bernanke (1983), Pindyck (1991), Lilien (1982), and Borenstein et al (1997) on the sources of the asymmetry, Barsky and Kilian (2004), Edelstein and Kilian (2007) on endogeneity of oil prices, and demandside concerns, Kliesen (2005) on manufacturing sector of the U.S., and Kilian (2008) for a detailed discussion about the literature.

${ }^{2}$ According to EIA Country Analysis Briefs : Turkey October 2006, Turkey accounts for $0.73 \%$ of world oil consumption as of 2005, and produces comparably negligible amount of oil.

${ }^{3}$ Based on Turkey State Planning Organization projections in 9th Development Plan Publication, Turkish Statistical Institute and Turkey General Directorate of Petroleum Affairs statistics, oil leads primary energy sources of Turkey by $36.68 \%$ and, $92.3 \%$ of the domestic demand is met by imports as of 2005 .

${ }^{4}$ According to Turkish Statistical Institute, expenditure on oil corresponds to $3.27 \%$ of Turkey's nominal GDP in 2005, and varies around $2.5 \%$ historically, as opposed to recent $1.3 \%$ of nominal GDP of the U.S. (Blanchard and Galí, 2007).
} 
Figure 1: Annualized Current Account Balance of Turkey as a Ratio to Turkey's GDP

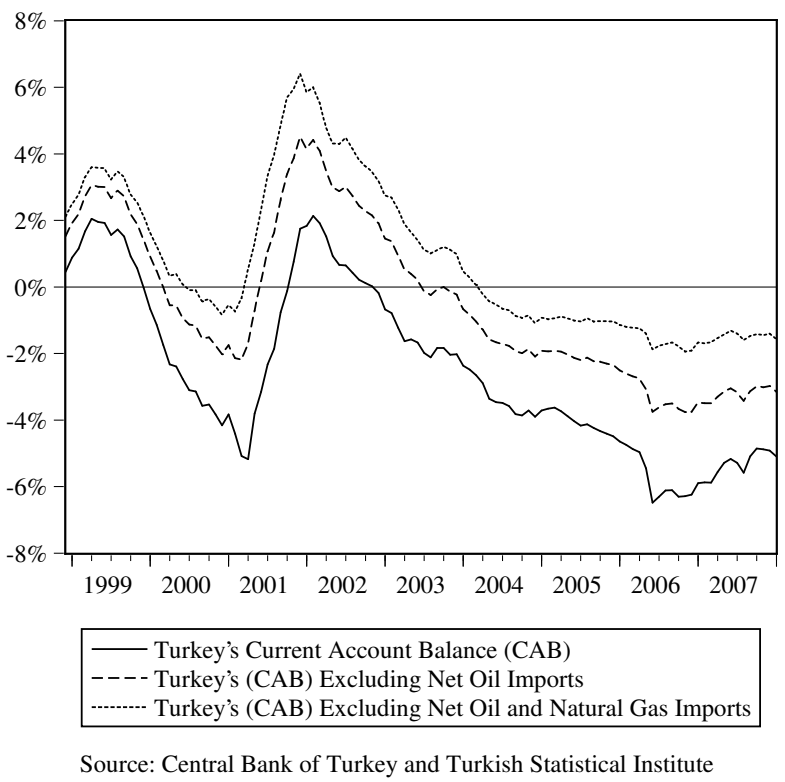

Third, as a financially liberalized small open economy, Turkey is more susceptible to sudden stops in capital flows, hence global liquidity conditions ${ }^{5}$. Therefore, we believe global liquidity conditions should be attempted to be taken into account while measuring the effect of oil price changes. ${ }^{6}$

Fourth, as a small open economy, Turkey's real GDP exhibits higher variability when compared to developed economies, and as a result of higher observed noise in output, estimating the net impacts of oil price changes is expected to be a more challenging task for Turkey ${ }^{7}$.

Finally, in Turkey direct and indirect taxes make up more than $60 \%$ of the prices of major fuel types. Hence, other than changes in world oil prices, changes in the exchange rate movements as well as revenue concerns for the Turkish government play a role in determining

\footnotetext{
${ }^{5}$ A priori, the relationship between world oil prices and global liquidity conditions is ambiguous: As a result of rising oil prices, capital account surpluses of OPEC and other major oil exporting countries could improve global liquidity conditions. On the other hand, due to increase in petrodollars, the resultant current account deficits of oil importers will have the opposite effect.

${ }^{6}$ See Alper and Torul (2008)

${ }^{7}$ As opposed to the standard deviation of real GDP growth of the U.S. for the 1992-2007 period: 0.0049, Turkey has much higher volatility: 0.0627. Further, standard deviation of industrial production index growth of the U.S. is 0.0048 whereas it is 0.0510 for Turkey.
} 
the domestic oil product prices that the households and firms face. This generates another departure of the relationship between world oil prices and real output when compared to the other developed economies.

There are only a few studies which analyze the impacts of of energy prices on the Turkish economy. While most focus on the inflationary effects of oil price changes, some focus on real effects of energy prices and consumption. ${ }^{8}$

In this study, we empirically investigate the effects of world oil prices and domestic oil product prices on manufacturing sector and its sub-categories in Turkey. This study distinguishes from the previous studies mainly in three aspects. This paper is paper is first of its kind to examine the responses of manufacturing sub-sectors of Turkey to oil price changes. Following Alper and Torul (2008), we incorporate global liquidity conditions, as well as domestic financial conditions and exchange rate dynamics ${ }^{9}$. Also, we employ monthly data in our estimations even though majority of previous studies employ quarterly or less frequent data.

Our multivariate vector autoregression (VAR) estimation results for the 1991-2007 reveal that even though overall industrial production do not respond to either world oil prices or domestic oil product prices, 6 out of 22 manufacturing sub-sectors respond significantly to domestic oil product prices. Further, we also find evidence for the necessity of incorporation of global liquidity and domestic financial conditions, as well as real exchange rate dynamics in our estimations.

The outline of the paper is as follows: In section 2, we describe data and methodology. In section 3, we present our empirical results and section 4 concludes.

\footnotetext{
${ }^{8}$ For the impact of energy prices on inflation see Kibritçioğlu and Kibritçioğlu (1999), Kibritçioğlu (2003), Berument and Taşçı (2002), Diboğlu and Kibritçioğlu (2004), among others. For the real effects see Sarı and Soytaş $(2003,2004)$ and Lise and Monfort (2006) on the relationship between energy consumption and GDP, and Sarı and Soytaş (2007) on electricity consumption and value-added in manufacturing sector.

${ }^{9}$ While Blanchard and Galí (2007), argue for the diminishing effects of oil price increases in the 2000s, Alper and Torul (2008) report that when the global liquidity and finance conditions are controlled for, the negative effects of oil price shocks still persist for Turkey in the 2000s at aggregate level.
} 


\section{Data, Variable Definitions and Methodology}

In this section we present the variables employed in estimating the effects of oil price changes on real production series, and their data sources.

We utilize world crude oil prices as well as domestic oil product prices to measure the effects of oil price changes on the Turkish economy. While the use of the former price series is standard in the literature, we also employ the latter variable since decision makers base their energy input and consumption decisions on end-user oil product prices rather than world prices, and the fluctuations of the two real prices series have differed noticeably in the recent decades as shown in Figure 2. The different growth rates of the two series can be explained by the price asymmetry of domestic oil product prices when responding to world crude oil prices: We show that parallel to the findings by Alper and Torul (2009) for gasoline prices, the weighted oil product price index the details of which will be discussed shortly, is observed to respond positively and significantly to world oil price increases, they do not

Figure 2: Historical Pattern of Real Crude Oil Prices and Real Oil Product Price Index




Figure 3: Accumulated Response of Oil Product Price Index

Accumulated Response of Oil Derivative Price Index Change to One Standard Deviation Brent Oil Price Increase Innovation

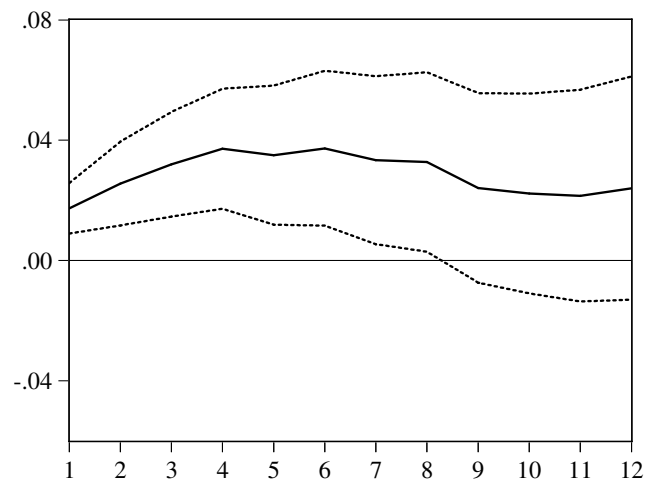

Accumulated Response of Oil Derivative Price Index Change to One Standard Deviation Brent Oil Price Decrease Innovation



respond significantly to oil price decreases as shown in Figure $3^{10,11}$.

The asymmetric response of domestic oil product prices to world crude oil prices could be attributed to three reasons. First, as a result of time-varying substantial government taxes on major oil products, the price changes which households and firms face differ from the world crude oil price fluctuations. As shown in Table 1, Turkish government alters the tax rates on the the two major types historically, which constitute no less than $60 \%$ of the final prices ${ }^{12}$. Following Alper and Torul (2009), it is reasonable to believe that taxes are the major contributor to the price asymmetry.

\footnotetext{
${ }^{10}$ Using a basic trivariate vector autoregression (VAR) model for 1991-2007 period with Brent oil price increase and decrease, and domestic oil product price index as three separate endogenous variables, and a constant and a dummy for Turkey's 1994 and 2001 financial crises as exogenous variables, we derive and display the resultant accumulated impulse-response functions.

${ }^{11}$ Additionally, Block-exogeneity Wald test results suggest that crude oil price increases significantly predict oil product price changes, whereas oil price decreases do not with the respective $p$ values of 0.024 and 0.3268 . Equivalent statistical results are observed with different modeling approaches.

${ }^{12}$ As a result of these various direct and indirect taxes, Turkish consumers pay the highest prices for light fuel oil, automotive diesel oil and unleaded gasoline, and second highest price for heavy fuel oil in the world. (International Energy Agency Key World Energy Statistics 2007)
} 


\begin{tabular}{|l|c|c|c|c|c|c|c|c|c|}
\hline Table 1: Tax Rates and Prices For Gasoline and Diesel Oil \\
\hline Gasoline 95 Octane & $\mathbf{1 9 9 8}$ & $\mathbf{1 9 9 9}$ & $\mathbf{2 0 0 0}$ & $\mathbf{2 0 0 1}$ & $\mathbf{2 0 0 2}$ & $\mathbf{2 0 0 3}$ & $\mathbf{2 0 0 4}$ & $\mathbf{2 0 0 5}$ & $\mathbf{2 0 0 6}$ \\
\hline Distillery Output Price & 0.034 & 0.067 & 0.160 & 0.253 & 0.303 & 0.361 & 0.459 & 0.551 & 0.695 \\
\hline Tax-added Price & 0.173 & 0.321 & 0.518 & 0.860 & 1.320 & 1.616 & 1.772 & 2.260 & 2.429 \\
\hline End-consumer Price & 0.203 & 0.364 & 0.584 & 0.995 & 1.481 & 1.799 & 1.979 & 2.550 & 2.790 \\
\hline Direct and Indirect Taxes & $80.3 \%$ & $79.0 \%$ & $69.1 \%$ & $70.6 \%$ & $76.9 \%$ & $77.7 \%$ & $74.1 \%$ & $75.6 \%$ & $71.4 \%$ \\
\hline Diesel Oil & $\mathbf{1 9 9 8}$ & $\mathbf{1 9 9 9}$ & $\mathbf{2 0 0 0}$ & $\mathbf{2 0 0 1}$ & $\mathbf{2 0 0 2}$ & $\mathbf{2 0 0 3}$ & $\mathbf{2 0 0 4}$ & $\mathbf{2 0 0 5}$ & $\mathbf{2 0 0 6}$ \\
\hline Distillery Output Price & 0.027 & 0.057 & 0.145 & 0.233 & 0.280 & 0.348 & 0.452 & 0.602 & 0.747 \\
\hline Tax-added Price & 0.102 & 0.206 & 0.380 & 0.629 & 0.965 & 1.238 & 1.363 & 1.697 & 1.867 \\
\hline End-consumer Price & 0.125 & 0.240 & 0.432 & 0.724 & 1.099 & 1.389 & 1.537 & 1.940 & 2.200 \\
\hline Direct and Indirect Taxes & $73.6 \%$ & $72.5 \%$ & $61.8 \%$ & $62.5 \%$ & $71.0 \%$ & $71.9 \%$ & $66.8 \%$ & $64.5 \%$ & $60.0 \%$ \\
\hline Source: Petroleum Industry Association of Turkey (PETDER) & & & & \\
\hline
\end{tabular}

Second, when the Turkish Lira fluctuates against the U.S. dollar in which world crude oil price is denominated, the domestic prices of oil products vary even during the periods when world oil prices are constant.

Third, because the basket of goods used in constructing the Turkish and the U.S. consumer price indices (CPIs) differ, when nominal world and domestic oil price series are deflated using these, then real series differ. This suggests that the growth rate of the two real series will also depend on the relative price changes of the other goods in the CPI bundles.

We construct the mentioned domestic nominal oil product price index variable as follows: We first acquire the monthly average end-user nominal prices from Petrol Ofisi Incorporation $(P O A S \zeta)$ for the five major oil product types, diesel oil, gasoline, kerosene, heating oil and fuel oil, which account for almost the entire consumption on oil products. Using these nominal prices, a nominal index of oil product prices is generated based on the relative weights of the oil products ${ }^{13}$. Real domestic oil product price series is obtained after deflating the nominal series by Turkish $\mathrm{CPI}^{14}$.

\footnotetext{
${ }^{13}$ For weighting purposes, we made use of annual consumption expenditure data on the major oil products by Turkey General Directorate of Petroleum Affairs.

${ }^{14} \mathrm{CPI}$ excluding energy prices is available only recently for Turkey. Hence we deflate the nominal domestic oil product prices with CPI including energy prices.
} 
Other than the growth rate of price index, in order to proxy asymmetric effects of oil price changes as documented in the literature, we employ three non-linear series: Mork's (1989) Oil Price Increase, Lee et al's (1995) Scaled Oil Price Increase (SOPI), Hamilton's (1996) Net Oil Price Increase (NOPI) ${ }^{15}$.

The first non-linear series, which is oil price increase variable due to Mork (1989) is defined as:

$$
o_{t}^{+}= \begin{cases}o_{t} & \text { if } o_{t}>0 \\ 0 & \text { else. }\end{cases}
$$

where $o_{t}$ denotes log-difference of oil product price index.

Lee, et al's (1995) SOPI series was derived using $\mathrm{AR}(4)-\mathrm{GARCH}(1,1)$ specification for quarterly frequency. We use monthly data, hence use $\mathrm{AR}(12)-\mathrm{GARCH}(1,1)$ specification:

$$
o_{t}=\alpha_{0}+\alpha_{1} o_{t-1}+\alpha_{2} o_{t-2}+\ldots+\alpha_{12} o_{t-12}+u_{t}
$$

where

$$
\begin{gathered}
\left(u_{t} \mid u_{t-1}\right) \sim N\left(0, \sigma_{t}^{2}\right) \quad \sigma_{t}^{2}=\gamma_{0}+\gamma_{1} \sigma_{t-1}^{2}+u_{t-1}^{2} \\
S O P I_{t}=\max \left\{0,\left(\hat{u}_{t} / \hat{\sigma}_{t}\right)\right\}
\end{gathered}
$$

Following Hamilton (1996), NOPI based on maximum price over 3 years is defined as:

$$
N O P I_{t}^{36}=\max \left\{0, p_{t}-\max \left(p_{t-1}, p_{t-2}, \ldots, p_{t-36}\right)\right\}
$$

where $p_{t}$ denotes the natural logarithm of nominal oil product price index.

In order to examine the net effects of oil product price changes on Turkish real sec-

\footnotetext{
${ }^{15}$ While there are further specifications in the literature, such as Ferderer's (1996) volatility-based nonlinear variable, following Hamilton (2003) who argue that SOPI and NOPI perform better than the rest of the price specifications in capturing the asymmetric effects of oil price shocks, we employ these variables. In addition, as a fundamental yet practical and reasonable threshold variable, we also use oil price increase specification in our estimations.
} 
tor, we employ industrial production index and manufacturing sub-sector indices as output variables, which are available on Central Bank of Turkey's (CBT) online database. We also incorporate macroeconomic fundamentals including domestic overnight interest rate and real effective exchange rate (REER) based on producer price index, which we obtain from CBT's online database. Additionally, we include two variables to proxy global liquidity conditions as used in the international financial literature: Effective Fed Funds Rate (FFR) and the Chicago Board of Exchange Implied Volatility Index (VIX) which are available in St. Louis Fed, and the Chicago Board of Exchange online databases, respectively. Since domestic interest rate and VIX data series are available after 1990, our estimation sample covers $1990-2007^{16,17}$.

We conduct the following set of estimations: We use multivariate VAR models with one of the oil price specifications, one of the real production indices, FFR, VIX, domestic overnight average interest rate, and REER. Other than these endogenous variables, we include a constant and a dummy variable for the 1994 and 2001 financial crises of Turkey as the exogenous variables.

After determining the optimal lag-length of the VAR models by log-likelihood ratio criterion, we compute the sum of oil product price coefficients as indicators of the responses of growth rates of industrial output indices, and conduct block-exogeneity Wald tests to check for significant uni-directional causality from oil product prices to output. Finally, we calculate the adjusted R-squared values, and use these as a measure for goodness of fit for the regressions.

\footnotetext{
${ }^{16}$ Because the data for manufacturing of wood and wood products industry is available only after 1997, for this specific industry our estimations cover the 1997-2007 period.

${ }^{17}$ While the seasonally-adjusted real oil product price index, real industrial output indices, and real effective exchange variables are observed to have unit root, and are included in estimations in log-difference forms, the remaining variables, VIX and interest rates are found to be stationary at levels, and hence included as they are.
} 


\section{Empirical Results}

First, using world crude oil prices as oil price specifications, we estimate multivariate VARs, and observe that except for manufacture of coke and refined petroleum products, none of the manufacturing sub-sector growth is predicted significantly by all linear and non-linear crude oil price variables ${ }^{18}$.

Next, employing symmetric and asymmetric domestic oil product price index variables in our multivariate VAR estimations, we find different results and heterogenous effects on sub-sectors. We report our findings in Table 2. Each row displays the VAR results of a manufacturing sub-sector for each of the oil price specifications. The first column refers to the leg-length, second column refers to the sum of oil coefficients, and the third column refers to the adjusted R-squared value for the specific regression.

Our optimal lag-lengths are observed to be no less than 12 months for majority of the regressions, which imply that in order for oil price changes to be reflected fully on manufacturing sector and the sub-categories, it takes no less than 4 quarters using the first three of the oil specifications and slightly shorter horizons using SOPI. These optimal lag-length results are in accordance with the 4 quarterly lags of Hamilton (1983, 1996, 2001), Hooker (1996), Mork (1989), Jiménez-Rodríguez and Sánchez (2005) for developed aggregate economies, and 13 months of Alper and Torul (2008) for Turkey aggregate output, but distinguishably longer than Kliesen's (2005) for the U.S. manufacturing sub-sectors.

According to the block-exogeneity tests, we observe that neither total industrial output growth nor aggregate manufacturing production growth is predicted significantly by oil product price changes. Further, while the endogenous variables altogether predict industrial output growth at $10 \%$ significance level regardless of the price specifications, they fail to predict overall manufacturing production growth seperately ${ }^{19}$.

Regarding the sub-sectors, we find that increase in domestic oil product prices signif-

\footnotetext{
${ }^{18}$ For brevity, we do not present the results of these estimations. All the results are available from the corresponding author upon request.

${ }^{19}$ Except for oil product price increase variable, which is significant at $10.58 \%$ significance level.
} 
icantly reduce the real growth rate of wood and wood products, chemicals and chemical products, rubber and plastic products, and furniture sectors regardless of price specifications. Of these sub-sectors, negative and significant impacts of oil product price increases on chemicals, chemical products, rubber and plastic products sectors are rather expected: these sub-sectors use oil products heavily as both production inputs and primary sources of energy according to previous energy surveys. The cause of negative and significant impacts on wood, wood products and furniture sectors is less clear given these sub-sectors are less oil-reliant than many of the other surveyed sub-sectors. 


\begin{tabular}{|c|c|c|c|c|c|c|c|c|c|c|c|c|}
\hline & \multicolumn{3}{|c|}{ Log-Difference } & \multicolumn{3}{|c|}{ Increase } & \multicolumn{3}{|c|}{ NOPI } & \multicolumn{3}{|c|}{ SOPI } \\
\hline & $p$ & $\sum \Gamma_{o i l}$ & $\overline{\mathrm{R}}^{2}$ & $p$ & $\sum \Gamma_{\text {oil }}$ & $\overline{\mathrm{R}}^{2}$ & $p$ & $\sum \Gamma_{\text {oil }}$ & $\overline{\mathrm{R}}^{2}$ & $p$ & $\sum \Gamma_{o i l}$ & $\overline{\mathrm{R}}^{2}$ \\
\hline Total Industry & 12 & 0.14 & 0.51 & 12 & 0.03 & 0.51 & 12 & 0.12 & 0.52 & 12 & 0.01 & 0.53 \\
\hline Manufacturing Industry & 13 & 0.24 & 0.48 & 12 & 0.06 & 0.46 & 12 & 0.07 & 0.47 & 12 & 0.01 & 0.48 \\
\hline Food and Beverage Prod. & 15 & 0.93 & 0.45 & 13 & 0.41 & 0.41 & 15 & 0.95 & 0.47 & 7 & -0.03 & 0.43 \\
\hline Tobacco Prod. & 12 & 0.63 & 0.33 & 12 & 0.01 & 0.33 & 12 & 0.12 & 0.34 & 12 & 0.03 & 0.34 \\
\hline Textile & 13 & 0.40 & 0.49 & 12 & -0.07 & 0.48 & 12 & 0.45 & 0.49 & 12 & -0.01 & 0.48 \\
\hline Wearing Apparel & 13 & 0.10 & 0.33 & 13 & $0.33^{*}$ & 0.35 & 13 & 0.47 & 0.34 & 6 & $0.00^{* *}$ & 0.39 \\
\hline Leather Prod. & 13 & -1.13 & 0.22 & 13 & 0.37 & 0.21 & 13 & -0.14 & 0.18 & 12 & -0.04 & 0.18 \\
\hline Wood and Wood Prod. & 15 & $-2.89^{* *}$ & 0.52 & 2 & $-1.32^{* *}$ & 0.22 & 2 & $-0.52^{*}$ & 0.18 & 7 & $-0.09^{* *}$ & 0.40 \\
\hline Paper and Paper Prod. & 13 & 0.50 & 0.28 & 12 & 0.31 & 0.28 & 12 & 0.32 & 0.30 & 7 & 0.00 & 0.29 \\
\hline Publishing and Recorded Media & 13 & -0.29 & 0.12 & 12 & 0.61 & 0.13 & 12 & 0.00 & 0.17 & 7 & -0.03 & 0.17 \\
\hline Coke and Refined Oil Prod. & 13 & -1.36 & 0.22 & 13 & -0.62 & 0.18 & 13 & -0.88 & 0.20 & 7 & -0.04 & 0.19 \\
\hline Chemicals and Chemical Prod. & 15 & $-0.92^{* *}$ & 0.27 & 12 & $-1.54^{* *}$ & 0.31 & 15 & $-1.25^{* *}$ & 0.27 & 3 & $-0.06^{* *}$ & 0.16 \\
\hline Rubber and Plastics Prod. & 13 & $-0.28^{* *}$ & 0.48 & 12 & $-0.59^{* *}$ & 0.45 & 12 & $-0.60^{*}$ & 0.45 & 7 & $-0.02^{* *}$ & 0.41 \\
\hline Other Non-Metallic Min. Prod. & 12 & -0.49 & 0.44 & 12 & 0.01 & 0.43 & 12 & -0.46 & 0.45 & 12 & 0.01 & 0.45 \\
\hline Basic Metals & 12 & $0.05^{* *}$ & 0.22 & 12 & $0.18^{* *}$ & 0.21 & 12 & $0.00^{*}$ & 0.19 & 6 & 0.01 & 0.21 \\
\hline Fabricated Metal Prod. & 12 & -0.26 & 0.15 & 12 & $-2.38^{* *}$ & 0.21 & 12 & -0.97 & 0.17 & 12 & -0.06 & 0.14 \\
\hline Machinery and Equipment & 13 & 0.17 & 0.47 & 12 & -0.08 & 0.45 & 12 & -0.03 & 0.46 & 10 & 0.02 & 0.46 \\
\hline Office and Computing Mach. & 14 & $4.33^{* *}$ & 0.29 & 14 & $2.57^{* *}$ & 0.28 & 13 & $5.73^{* *}$ & 0.31 & 12 & 0.13 & 0.19 \\
\hline Electrical Machinery n.e.c. & 13 & $0.97^{* *}$ & 0.50 & 12 & $-2.34^{* *}$ & 0.53 & 12 & $-2.38^{* *}$ & 0.52 & 12 & $-0.06 * *$ & 0.45 \\
\hline Radio, TV and Commun. App. & 13 & $1.44^{* *}$ & 0.55 & 13 & $-1.10^{* *}$ & 0.57 & 13 & $-0.07 * *$ & 0.56 & 12 & $-0.01^{*}$ & 0.46 \\
\hline Medical and Optical Instrum. & 12 & 1.83 & 0.32 & 12 & $5.48^{*}$ & 0.37 & 12 & 1.48 & 0.35 & 12 & 0.27 & 0.35 \\
\hline Motor Vehicles,etc. & 12 & 1.39 & 0.29 & 12 & 2.00 & 0.28 & 12 & 0.84 & 0.30 & 12 & 0.08 & 0.27 \\
\hline Other Transport Equipment & 13 & 8.29 & 0.27 & 13 & 12.66 & 0.28 & 12 & 12.07 & 0.30 & 12 & 0.58 & 0.27 \\
\hline Furniture & 13 & $-0.97^{* *}$ & 0.35 & 13 & $-3.90^{* *}$ & 0.45 & 13 & $-2.33^{* *}$ & 0.33 & 7 & $-0.11^{* *}$ & 0.23 \\
\hline$p:$ Lag-Length Determined by & & . & 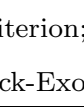 & & 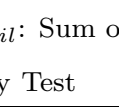 & & & 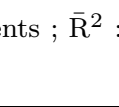 & & & a & \\
\hline
\end{tabular}

Additionally, electrical machinery and radio, television and communication apparatus sectors are predicted significantly by all price specifications. Except for price growth variable which fails to capture the asymmetric effect, unfavorable consequences of oil product price increases on these manufacturing sub-sectors is significantly documented. Regarding these two sub-sectors, previous surveys indicate that oil products are not the primary sources of energy, and have smaller share of oil relative to many other sectors. Given that some other sub-sectors such as food and beverage products use higher portion of energy from oil prod- 
ucts, and are not significantly predicted by oil product price increases, the main reason of the significant effects on these industries are not very clear, either ${ }^{20}$.

For the remaining sectors, only manufacture of basic metals and office and computing machinery are observed to be potential candidates to be predicted by oil product price changes as they respond significantly and positively to all price specifications but SOPI. However, since SOPI, by definition, captures the unexpected increases in prices better than the other specifications, positive uni-directional causality from domestic oil product prices to growth of these sub-sectors is not likely.

One manufacturing sub-sector of special interest, namely the manufacture of motor vehicles is observed not to be significantly effected by oil product price increases. A priori, one would expect the this sub-sector to be negatively affected by oil price increases as a result of lower demand because of higher operating $\operatorname{costs}^{21}$. Perhaps, higher operating costs for motor vehicles create incentives for fuel-efficient motor vehicles, and accordingly opportunities for the automobile producers of these types. Hence, rather than an overall reduction in the industry, substitution to fuel-efficient cars is more probable, yielding overall insignificance of the response of the output of this sub-sector.

Block-exogeneity tests on the significantly-predicted sub-sectors reveal that additional variables in our multivariate VAR models heterogeneously predict the growth of manufacturing sub-sectors ${ }^{22}$. Further, the exclusion of these additional variables result in decrease in statistical significance of the predictive power of oil prices, deterioration of adjusted Rsquared values, and reversion in the sign of sum of oil coefficient for many sub-sectors. Hence,

\footnotetext{
${ }^{20}$ Our findings are similar to those of Kliesen (2005) who document negative and significant impacts of oil price increases on manufacture of wood and furniture products, and fabricated metal products of the U.S. economy.

${ }^{21}$ Further, automobile industry is documented to be the the main source of unfavorable supply-side impacts of oil prices for the U.S. economy by Kilian, 2008.

${ }^{22}$ Effective Fed funds rate predict growth of manufacture of wood and wood products, furniture and basic metals; implied volatility index predict growth of manufacture of rubber and plastic products, electrical machinery, and radio, television and communication apparatus; domestic interest rate predict growth of manufacture of chemicals and chemical products, radio, television and communication apparatus; and real effective exchange rate predict growth of wood and wood products, radio, television and communication apparatus sectors, significantly.
} 
in the light of these findings, incorporation of global liquidity conditions, as well as domestic finance and exchange rate dynamics are critical in estimating the net effect of oil price changes, and exclusion of these factors may lead to omitted variable bias.

\section{Conclusion}

Investigating the relationship between oil price and macroeconomy has been an issue of interest in the recent decades. While numerous studies have been conducted and substantial progress have been achieved on developed economies, particularly on the U.S. economy, the dynamics for emerging small open economies have not been revealed, yet.

In this study, we investigate the effects of world oil and domestic oil product price changes on manufacturing sub-sectors of Turkey.

Using linear, and non-linear oil price variables in the literature, and incorporating global liquidity and domestic finance conditions, as well as real exchange rate dynamics, we perform multivariate VARs in order to estimate the net effect of oil price changes.

We report that contrary to the common belief, neither crude oil nor oil product price increases impede overall production growth of Turkey. Yet, we find out that oil product price increases robustly impede production growth of several manufacturing sub-sectors, including wood and wood products, furniture, chemicals and chemical products, and rubber and plastic products, electrical machinery, and radio, TV and communication apparatus. Further, we present evidence on the necessity of incorporation of the additional variables in our estimations. 


\section{References}

[1] Alper, C. E. (2002). "Business Cycles, Excess Volatility and Capital Flows: Evidence from Mexico and Turkey." Russian and East European Finance and Trade 38(4): 22-54.

[2] Alper, C. E. and O. Torul (2008). "Oil Prices, Aggregate Economic Activity and Global Liquidity Conditions: Evidence from Turkey." Economics Bulletin 17(4): 1-8.

[3] Alper, C. E. and O. Torul (2009). "Asymmetric adjustment of retail gasoline prices in turkey to world crude oil price changes: the role of taxes." Economics Bulletin 29(2): 789-802.

[4] Barsky, R. B. and L. Kilian (2004). "Oil and the Macroeconomy since the 1970s." The Journal of Economic Perspectives 18(4): 115-134.

[5] Bernanke, B. S. (1983). "Irreversibility, Uncertainty, and Cyclical Investment." Quarterly Journal of Economics 98(1): 85-106.

[6] Berument, H. and H. Taş̧̧ı (2002). "Inflationary Effect of Crude Oil Prices in Turkey." Physica A 316(1): 568-580.

[7] Blanchard, O. and J. Galí (2007). "The Macroeconomic Effects of Oil Price Shocks: Why are the 2000s so Different from the 1970s?" Working Paper 13368, National Bureau of Economic Research (NBER)

[8] Borenstein, S. A., C. Cameron and R. Gilbert (1997). "Do Gasoline Prices Respond Asymmetrically to Crude Oil Price Changes?" The Quarterly Journal of Economics 112(1): 305-339.

[9] Brown, S. P. A. and M. K. Yücel (2008). "What Drives Natural Gas Prices?" The Energy Journal 28(2): 45-60.

[10] Diboğlu, Sel and Aykut Kibritçioğlu (2004). "Inflation, output growth and stabilization in Turkey, 1980-2002" Journal of Economics and Business 56(1) 43-61. 
[11] Edelstein, P. and L. Kilian (2007). "Retail Energy Prices and Consumer Expenditures" Discussion Paper 6255, Centre for Economic Policy Research (CEPR)

[12] Ferderer, P. J. (1996). "Oil Price Volatility and the Macroeconomy." Journal of Macroeconomics 18(1): 1-26.

[13] Friedman, M. (1962). "The Interpolation of Time Series by Related Series." Journal of the American Statistical Association 57(300): 729-757.

[14] Hamilton, J. D. (1983). "Oil and the Macroeconomy since World War II." Journal of Political Economy 91(2): 228-248.

[15] Hamilton, J. D. (1996). "This is What Happened to the Oil Price-Macroeconomy Relationship." Journal of Monetary Economics 38(2): 215-220.

[16] Hamilton, J. D. (2003). "What is an Oil Shock?" Journal of Econometrics 113(2): 363398.

[17] Hooker, M. A. (1996). "What Happened to the Oil price-Macroeconomy Relationship?" Journal of Monetary Economics 38(3): 195-213.

[18] Jiménez-Rodríguez, R. and M. Sánchez (2005). "Oil Price Shocks and Real GDP Growth: Empirical Evidence for Some OECD Countries" Applied Economics 37(2): 201-228.

[19] Kavak, K. (2005). "Dünyada ve Türkiye'de Enerji Verimliliği ve Türk Sanayiinde Enerji Verimliliğinin İncelenmesi." Yayın No: 2689 Devlet Planlama Teşkilatı (DPT) İktisadi Sektörler ve Koordinasyon Genel Müdürlüğü (In Turkish).

[20] Kibritçioğlu, A. and B. Kibritçioğlu (1999). "Ham petrol ve akaryakıt ürünü fiyat artışlarının Türkiye'deki enflasyonist etkileri." Hazine Müsteşarlığı Ekonomik Araştırmalar Genel Müdürlüğü Araştırma ve İnceleme Dizisi, No. 21 (In Turkish). 
[21] Kibritçioğlu, A. (2003). "Changes in Prices of Oil Products and Inflation in Turkey: New Evidence." Working Paper 0306005, The Economics Working Paper Archive (EconWPA) Macroeconomics

[22] Kilian, L. (2008). "The Economic Effects of Energy Price Shocks." Journal of Economic Literature 46(4): 871-909.

[23] Kliesen, K. L. (2006). "Rising Natural Gas Prices and Real Economic Activity." Federal Reserve Bank of St. Louis Review 88(6): 511-526.

[24] Lee, K., S. Ni, and R. A. Ratti (1995). "Oil Shocks and the Macroeconomy: The Role of Price Variability." The Energy Journal 16(4): 39-56.

[25] Lilien, D. M. (1982). "Sectoral Shifts and Cyclical Unemployment." Journal of Political Economy 90(4): 777-793.

[26] Lise, W. and K. Van Montfort (2007). "Energy Consumption and GDP in Turkey: Is There a Co-integration Relationship?" Energy Economics 29(6): 1166-1178.

[27] Mork, K. A. (1989). "Oil Shocks and the Macroeconomy When Prices Go Up and Down: An Extension of Hamilton's Results." Journal of Political Economy 97(4): 740-744.

[28] Pindyck, R. (1991). "Irreversibility, Uncertainty, and Investment." Journal of Economic Literature 29(3): 110-148.

[29] Sarı, R. and U. Soytaş (2003). "Energy Consumption and GDP: Causality Relationship in G-7 Countries and Emerging Markets." Energy Economics 25(1): 33-37.

[30] Sarı, R. and U. Soytaş (2004). "Disaggregate Energy Consumption, Employment and Income in Turkey." Energy Economics 26(3): 335-344.

[31] Sarı, R. and U. Soytaş (2007). "The Relationship Between Energy and Production: Evidence from Turkish Manufacturing Industry." Energy Economics 29(6): 1151-1165. 


\section{Additional Appendix for Referees}

\begin{tabular}{|c|c|c|c|c|c|c|c|}
\hline & Year & Oil & Natural Gas & Coal* & Electricity & Others** & Overall Share \\
\hline \multirow[t]{2}{*}{ Food and Beverage } & 1995 & $36.23 \%$ & $7.12 \%$ & $21.37 \%$ & $33.81 \%$ & $1.48 \%$ & $7.40 \%$ \\
\hline & 2001 & $25.16 \%$ & $13.37 \%$ & $19.27 \%$ & $30.31 \%$ & $11.90 \%$ & $8.79 \%$ \\
\hline \multirow[t]{2}{*}{ Textile, Wearing and Leather } & 1995 & $27.83 \%$ & $11.65 \%$ & $3.89 \%$ & $55.51 \%$ & $1.12 \%$ & $10.18 \%$ \\
\hline & 2001 & $16.22 \%$ & $15.35 \%$ & $1.86 \%$ & $61.20 \%$ & $5.38 \%$ & $13.18 \%$ \\
\hline \multirow[t]{2}{*}{ Wood Product } & 1995 & $14.67 \%$ & $0.48 \%$ & $9.99 \%$ & $72.95 \%$ & $1.90 \%$ & $0.97 \%$ \\
\hline & 2001 & $14.47 \%$ & $29.58 \%$ & $2.12 \%$ & $52.00 \%$ & $1.84 \%$ & $1.08 \%$ \\
\hline \multirow[t]{2}{*}{ Paper products, and Publishing } & 1995 & $39.01 \%$ & $9.86 \%$ & $1.81 \%$ & $49.22 \%$ & $0.10 \%$ & $4.83 \%$ \\
\hline & 2001 & $34.72 \%$ & $16.82 \%$ & $0.69 \%$ & $41.03 \%$ & $6.74 \%$ & $4.13 \%$ \\
\hline \multirow[t]{2}{*}{ Chemicals Product } & 1995 & $38.74 \%$ & $26.30 \%$ & $3.70 \%$ & $28.90 \%$ & $2.37 \%$ & $15.97 \%$ \\
\hline & 2001 & $53.54 \%$ & $15.59 \%$ & $3.30 \%$ & $21.60 \%$ & $5.97 \%$ & $18.98 \%$ \\
\hline \multirow[t]{2}{*}{ Non-metallic Mineral } & 1995 & $13.71 \%$ & $5.07 \%$ & $24.32 \%$ & $46.13 \%$ & $10.77 \%$ & $26.01 \%$ \\
\hline & 2001 & $19.51 \%$ & $12.75 \%$ & $17.88 \%$ & $40.11 \%$ & $9.75 \%$ & $23.85 \%$ \\
\hline \multirow[t]{2}{*}{ Iron and Steel Basic } & 1995 & $17.02 \%$ & $5.90 \%$ & $36.48 \%$ & $40.33 \%$ & $0.27 \%$ & $31.09 \%$ \\
\hline & 2001 & $14.93 \%$ & $13.14 \%$ & $32.20 \%$ & $39.27 \%$ & $0.46 \%$ & $26.36 \%$ \\
\hline \multirow[t]{2}{*}{ Non-ferrous Metal Basic } & 1995 & $31.26 \%$ & $1.66 \%$ & $6.09 \%$ & $55.54 \%$ & $5.45 \%$ & $3.53 \%$ \\
\hline & 2001 & $17.08 \%$ & $5.51 \%$ & $2.12 \%$ & $69.04 \%$ & $6.25 \%$ & $3.63 \%$ \\
\hline \multirow[t]{2}{*}{ Fabricated Metal } & 1995 & $20.44 \%$ & $8.24 \%$ & $2.70 \%$ & $67.94 \%$ & $0.69 \%$ & $4.96 \%$ \\
\hline & 2001 & $19.44 \%$ & $9.76 \%$ & $1.57 \%$ & $61.60 \%$ & $7.64 \%$ & $5.27 \%$ \\
\hline \multirow[t]{2}{*}{ Total } & 1995 & $23.69 \%$ & $9.61 \%$ & $20.64 \%$ & $42.36 \%$ & $3.70 \%$ & $100.00 \%$ \\
\hline & 2001 & $25.31 \%$ & $13.87 \%$ & $15.45 \%$ & $39.51 \%$ & $5.86 \%$ & $100.00 \%$ \\
\hline \multicolumn{8}{|c|}{$\begin{array}{l}\text { * Coal, Lignite and Coke } \\
{ }^{* *} \text { Kerosene,wood, petroleum coke, naphtha, acetylene, propane, bitumen, and others }\end{array}$} \\
\hline
\end{tabular}




\begin{tabular}{|c|c|c|c|c|c|c|c|c|c|c|c|c|}
\hline & \multicolumn{3}{|c|}{ Log-Difference } & \multicolumn{3}{|c|}{ Increase } & \multicolumn{3}{|c|}{ NOPI } & \multicolumn{3}{|c|}{ SOPI } \\
\hline & $p$ & $\sum \Gamma_{\text {oil }}$ & $\overline{\mathrm{R}}^{2}$ & $p$ & $\sum \Gamma_{o i l}$ & $\overline{\mathrm{R}}^{2}$ & $p$ & $\sum \Gamma_{o i l}$ & $\overline{\mathrm{R}}^{2}$ & $p$ & $\sum \Gamma_{o i l}$ & $\overline{\mathrm{R}}^{2}$ \\
\hline Total Industry & 14 & 0.08 & 0.48 & 13 & 0.04 & 0.47 & 13 & 0.02 & 0.48 & 14 & 0.00 & 0.49 \\
\hline Manufacturing Industry & 14 & 0.14 & 0.43 & 13 & 0.04 & 0.43 & 13 & 0.02 & 0.44 & 14 & 0.01 & 0.45 \\
\hline Food and Beverage Prod. & 14 & 0.60 & 0.40 & 12 & -0.56 & 0.41 & 12 & $0.08^{* *}$ & 0.43 & 6 & -0.03 & 0.40 \\
\hline Tobacco Prod. & 13 & 0.54 & 0.35 & 12 & -0.03 & 0.35 & 12 & 0.02 & 0.36 & 12 & 0.04 & 0.35 \\
\hline Textile & 14 & 0.38 & 0.44 & 13 & $0.33^{* *}$ & 0.46 & 7 & $0.23^{* *}$ & 0.43 & 5 & $0.00^{* *}$ & 0.41 \\
\hline Wearing Apparel & 14 & 0.45 & 0.35 & 13 & 0.41 & 0.36 & 13 & 0.23 & 0.36 & 4 & $0.01^{* *}$ & 0.35 \\
\hline Leather Prod. & 13 & -1.00 & 0.25 & 13 & 0.38 & 0.25 & 13 & -0.16 & 0.23 & 2 & 0.00 & 0.23 \\
\hline Wood and Wood Prod. & 11 & -0.10 & 0.24 & 1 & $-0.95^{* *}$ & 0.18 & 2 & $-0.51^{* *}$ & 0.18 & 9 & $-0.02^{*}$ & 0.25 \\
\hline Paper and Paper Prod. & 13 & 1.16 & 0.27 & 13 & 0.57 & 0.27 & 13 & 0.25 & 0.26 & 10 & 0.04 & 0.25 \\
\hline Publishing and Recorded Media & 13 & 0.55 & 0.16 & 13 & 0.27 & 0.16 & 11 & 0.12 & 0.16 & 10 & 0.01 & 0.16 \\
\hline Coke and Refined Oil Prod. & 13 & -0.84 & 0.22 & 12 & -0.27 & 0.20 & 12 & -0.11 & 0.21 & 12 & -0.02 & 0.22 \\
\hline Chemicals and Chemical Prod. & 15 & $-0.72^{* *}$ & 0.23 & 15 & $-2.27^{* *}$ & 0.34 & 15 & $-0.73^{* *}$ & 0.26 & 15 & $-0.13^{* *}$ & 0.21 \\
\hline Rubber and Plastics Prod. & 14 & $0.48^{* *}$ & 0.43 & 13 & $-0.01^{* *}$ & 0.41 & 13 & $0.11^{* *}$ & 0.41 & 13 & $0.02^{* *}$ & 0.42 \\
\hline Other Non-Metallic Min. Prod. & 13 & -0.28 & 0.39 & 13 & -0.42 & 0.39 & 13 & -0.27 & 0.41 & 13 & 0.01 & 0.39 \\
\hline Basic Metals & 13 & 0.05 & 0.20 & 12 & $-0.01^{*}$ & 0.19 & 13 & -0.08 & 0.22 & 13 & -0.01 & 0.19 \\
\hline Fabricated Metal Prod. & 13 & -0.36 & 0.14 & 13 & $-2.10^{* *}$ & 0.20 & 13 & -0.35 & 0.17 & 1 & $-0.03^{* *}$ & 0.13 \\
\hline Machinery and Equipment . & 14 & 0.52 & 0.38 & 13 & 0.65 & 0.39 & 11 & 0.37 & 0.38 & 10 & 0.03 & 0.38 \\
\hline Office and Computing Mach. & 14 & $4.10^{* *}$ & 0.21 & 13 & $1.56^{* *}$ & 0.20 & 13 & $0.96^{* *}$ & 0.20 & 12 & 0.11 & 0.12 \\
\hline Electrical Machinery n.e.c. & 14 & $1.03^{* *}$ & 0.46 & 13 & $-1.53^{* *}$ & 0.47 & 13 & $-0.49^{* *}$ & 0.47 & 12 & $-0.06^{*}$ & 0.40 \\
\hline Radio, TV and Commun. App. & 14 & $1.49^{* *}$ & 0.52 & 14 & $0.11^{* *}$ & 0.55 & 15 & $1.27^{* *}$ & 0.54 & 12 & $-0.03^{* *}$ & 0.42 \\
\hline Medical and Optical Instrum. & 13 & 1.07 & 0.28 & 12 & 2.61 & 0.30 & 12 & $0.58^{*}$ & 0.31 & 4 & $0.12^{*}$ & 0.26 \\
\hline Motor Vehicles,etc. & 13 & $0.87^{* *}$ & 0.24 & 12 & $1.24^{*}$ & 0.23 & 13 & $0.41^{* *}$ & 0.32 & 10 & 0.06 & 0.21 \\
\hline Other Transport Equipment & 13 & 5.69 & 0.18 & 12 & 4.01 & 0.16 & 12 & 1.62 & 0.17 & 12 & -0.03 & 0.18 \\
\hline Furniture & 15 & $-2.17^{* *}$ & 0.26 & 15 & $-5.81^{* *}$ & 0.37 & 15 & $-1.30^{* *}$ & 0.20 & 2 & $-0.20^{* *}$ & 0.20 \\
\hline
\end{tabular}


Figure 4: Consumption of Petroleum Products in Turkey

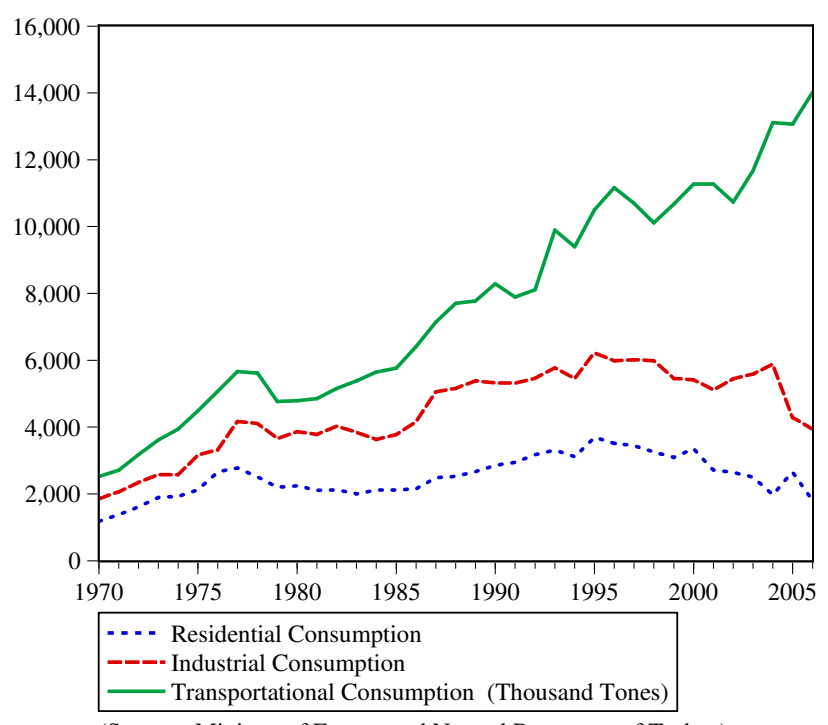

(Source : Ministry of Energy and Natural Resources of Turkey)

Figure 5: Sectoral Consumption of Energy in Turkey

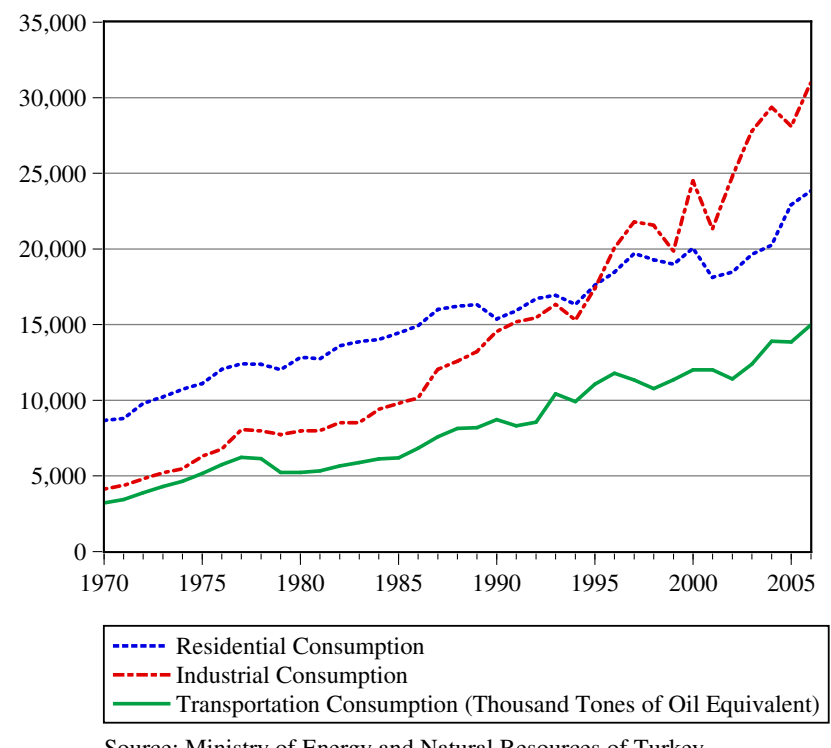

Source: Ministry of Energy and Natural Resources of Turkey 
Figure 6: Energy Consumption in Manufacturing Sector by Source



- Petroleum Consumption (Thousand Tones)

--- Natural Gas Consumption (Cubic Meters)

Source: Ministry of Energy and Natural Resources of Turkey

Figure 7: Real and Nominal Brent Oil Prices

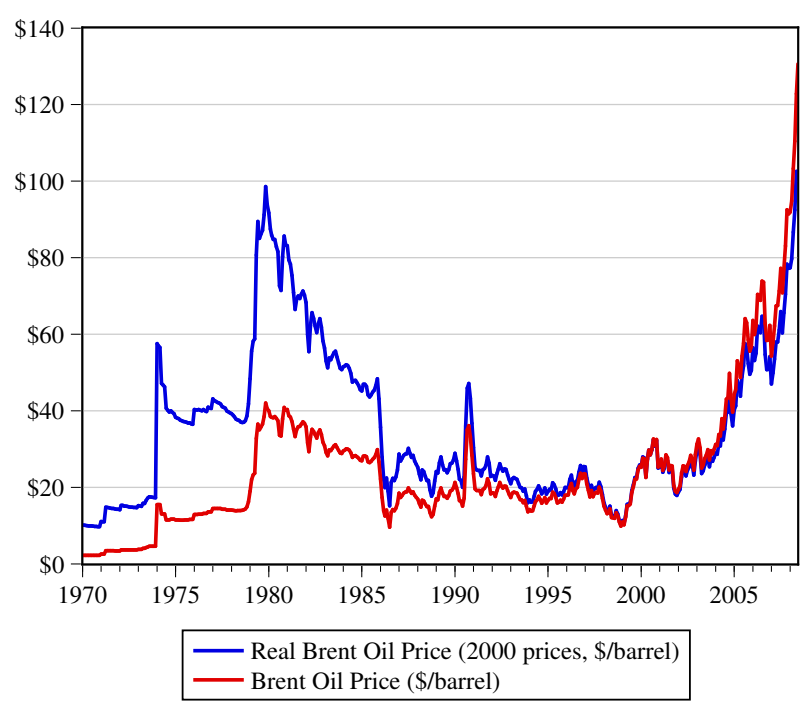

Source: Energy Information Administration (EIA) and Federal Reserve Economic Data (FRED) 
Figure 8: Oil Consumption as a Percentage to Turkey's GDP

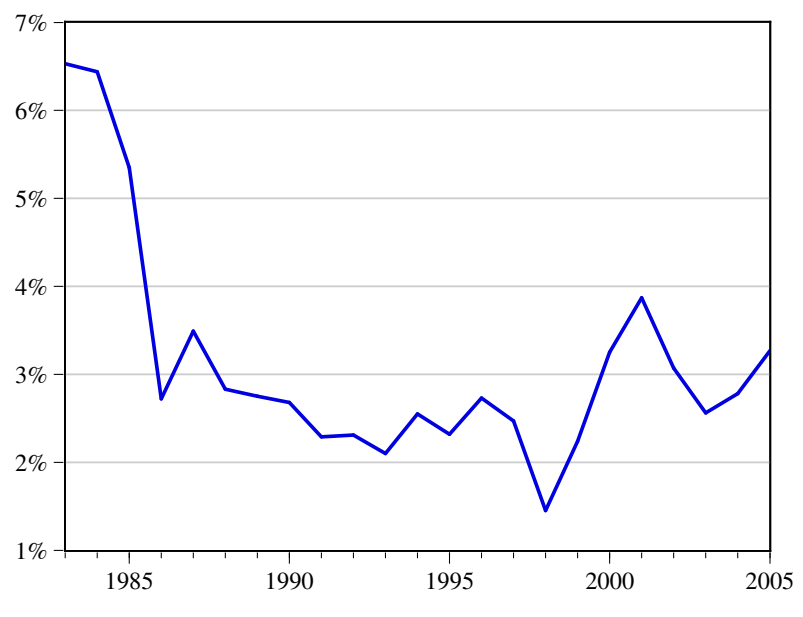

Source: Central Bank of Turkey and General Directorate of Petroleum Affairs 